BEduManageRs Journal

Borneo Educational Management and Research Journal, Vol.2, No.1, 2021

ISSN: 2747-0504

\title{
Pengaruh Motivasi Kerja Terhadap Kinerja Guru Di Masa Pandemi Covid 19
}

\author{
Irianto $^{1,}$ Junaini $^{2}$ \\ STTI Bontang Teknik Mesin \\ e-mail: iriantosmart@gmail.com jhunaini99@yahoo.co.id
}

\begin{abstract}
Teacher performance plays an important role in improving the quality of the learning process in an effort to improve the quality of education, especially at the Yabis Bontang educational institution. To achieve optimal learning, teacher work motivation should be high to be able to bring up better teacher performance, so that it can produce quality students and can continue school to a higher level.

The research was conducted to examine and find out how much influence teacher work motivation on teacher performance in schools in the Yabis Education Institute, from kindergarten, elementary, junior high and high school units. The method used in this research is ex post facto. To obtain the desired data in the field, this study used a questionnaire compiled using several indicators. The data needed in this study are data on teacher work motivation $(X)$, and teacher performance $(Y)$.

Based on the results of data processing and analysis, the following conclusions were obtained; 1)There is a positive influence between work motivation on teacher performance at the Yabis Al-ikhlas Bontang Education Foundation during the Covid 19 pandemic. and 2) Work motivation contributes $44 \%$ to teacher performance at the Yabis Bontang Foundation.
\end{abstract}

Keywords: Teacher performance, work motivation.

\section{PENDAHULUAN}

Kesadaran pemerintah Indonesia untuk meningkatkan mutu pendidikan semakin peduli dan sensitivitas yang tajam untuk melahirkan berbagai gagasan pendidikan yang dengan sadar memihak kepada kehidupan bangsa yang lebih cemerlang pada masa depan. Pembenahan sistim Pendidikan dewasa ini semakin banyak digalakkan dengan harapan pada masa mendatang akan meningkatkan sumberdaya manuisa yang terampil dan terdidik yang merupakan faktor determinan pembangunan bangsa.

Dalam mencapai tujuan pembenahan dibidang pendidikan tentu saja beberapa permasalahan perlu dikaji dan diantisipasi serta dicarikan jalan keluarnya sehingga mampu menjawab kebutuhan peserta didik, masyarakat, dan kemajuan ilmu pengetahuan dan teknologi yang secara gterus menerus berkembang sesuai dengan dinamika kehidupan masyarakat untuk mencapai tujuan, seperti fasilitas belajar, dana, kurikulum, guru, metode, dan kepala sekolah. Keseluruhan komponen tersebut adalah merupakan satu kesatuan yang saling berhubungan dan melengkapi. Kontribusi komponen yang lain seperti komponen tenaga kependidikan atau guru merupakan salah satu faktor yang sangat esensi dalam menentukan kualitas peserta didiknya, tanggung jawab yang diemban seorang guru telah menempatkan guru pada posisi yang paling strategis dalam keberhasilan proses pendidikan, guru juga mengemban tugas utama diantaranya membimbing para siswa agar mampu mengembangkan potensi-potensi keperibadian dan mengadaptasikan dirinya dengan berbagai kebutuhan dan perubahan yang acapkali ditemui dalam kehidupan masyarakat.

Rendahnya mutu pendidikan merupakan salah satu problem klasik yang dihadapi oleh negara berkembang kususnya Indonesia. Hal ini salah satunya dipengaruhi oleh masih rendahnya kinerja guru. Kinerja guru sangat berpengaruh terhadap kualitas proses pendidikan siswa yang berdampak pada hasil pembelajaran siswa, untuk mencapai pembelajaran yang optimal sekolah diharapkan dapat memotivasi guru agar kinerja 
BEduManageRs Journal

Borneo Educational Management and Research Journal, Vol.2, No.1, 2021

ISSN: 2747-0504

guru lebih baik, sehingga dapat menghasilkan siswa yang berkualitas dan melanjutkan sekolah ke sekolahlLanjutan tingkat atas atau karena kemampuan dan kesempatan sebagian masyarakat tidak dapat melanjutkan sekolah dan terpaksa harus bekerja.

Kenyataan di lapangan menunjukan bahwa masih banyak diantara guru masih belum dapat meningkatkan kinerjanya dengan berbagai alasan dan kinerja guru masih sulit diwujudkan. Kesulitan tersebut diakibatkan oleh beberapa faktor yang mempengaruhi, seperti: faktor individu (intrinsik) yang meliputi kemampuan, karakteristik, kecerdasan ilmu pengetahuan, dan tanggung jawab terhadap pekerjaan yang diemban, faktor lingkungan (ekstrinsik) yang meliputi sarana, prasarana, dan suasana kerja, serta faktor kepemimpinan dari kepala sekolah yang belum tepat dalam menerapkan praktek memimpin. Adapun fakta-fakta yang mempengaruhi kualitas kinerja guru diantaranya, guru belum maksimal dalam melaksanakan tugas, hal ini dapat terlihat dalam hasil ujian nasional, sarana dan prasarana masih minim, serta tidak memiliki progam kerja. Dalam hal ini pemerintah melakukan peningkatan kinerja guru dengan memberikan kemudahan peningkatan pendidikan ke jenjang yang lebih tinggi, memberikan bantuan fisik diantaranya sarana dan prasarana, memberikan pelatihan seperti seminar, workshop, meningkatkan kesejahtraan seperti fungsional dan kenaikan pangkat.

Yang menjadi perbincangan yang sering mengemuka diantaranya adalah guru . Masih banyak guru belum maksimal dalam melaksanakan tugas apalagi di masa pandemic Covid 19, hal ini dapat terlihat pada tingkat motivasi siswa,prestasi belajar, disiplin, kerjasama, keterampilan, dan beberapa bentuk kenakalan remaja yang sampai saat ini masih menjadi masalah yang hangat, sarana dan prasarana sekolah, serta banyak guru yang tidak memiliki progam kerja yang jelas karena kurangnya koordinasi baik dengan kepala sekolah maupun seluruh sivitas akademika sekolah.

Proses pembelajaran di kelas selalu melibatkan guru dan peserta didik dan tidak terlepas dari kegiatan belajar mengajar di sekolah. Kegiatan belajar mengajar sangat ditentukan oleh kerjasama antara guru dan peserta didik. Guru dituntut mampu menyajikan materi pelajaran dengan metoda yang menarik, menantang, dan menggugah siswa untuk melakukan aktifitas fisik secara optimal. Namun kenyataan menunjukkan bahwa masih banyak guru belum optimal dalam pembelajaran sehingga siswa belum terarahkan untuk memahami sendiri konsep-konsep pendidikan yang sedang dipelajari. Sehingga belum mampu mengembangkan kemampuan kognitif (penalaran), afektif (sikap), dan psikomotorik (keterampilan). Siswa cenderung melakukan aktifitas fisik dan pelajaran yang dipelajarinya tanpa memahami dengan benar apa tujuan dan makna yang terkandung di dalamnya. Akibatnya penguasaan guru sebagai pemberi dorongan, semangat dan mengatur informasi cenderung mendominasi pembelajaran , akibatnya seringkali proses hubungan timbal balik guru dan siswa kurang tertata degan baik yang berimplikasi terhadap kualitas pembelajaran pendidikan di sekolah.

Kinerja guru sangat berpengaruh terhadap kualitas pembelajaran dan pendidikan siswa, dan selanjutnya akan berdampak pada hasil pembelajaran siswa, untuk mencapai pembelajaran yang optimal, pihak pimpinan sekolah diharapkan dapat memotivasi guru agar kinerja guru lebih baik, sehingga dapat menghasilkan peserta didik yang berkualitas dan dapat melanjutkan sekolah ke tingkat sekolah lanjutan tingkat atas atau sebagian lagi terpaksa bekerja. Kenyataan di lapangan menunjukan bahwa peningkatan kinerja guru ternyata masih sulit diwujudkan. Banyak guru tidak melaksanakan tugasnya dengan baik, walaupun dengan adanya sertifikasi guru nampaknya kehadiran melaksanakan pembelajaran sudah tinggi, tetapi belum diimbangi dengan peningkatan kualitas pembelajaran yang berimbas kepada kualitas pendidikan di sekolah.

Melihat kondisi tersebut, sangat menarik untuk dilakukan penelitian dengan mengkaji hubungan antara motivasi kerja dengan kinerja guru di sekolah-sekolah yang ada dalam Lembaga pendidikan Yabis Bontang.

\section{KAJIAN TEORI}

\section{Kinerja Guru}

Kinerja merupakan konsep umum yang digunakan untuk mengetahui efektivitas pelaksanaan kerja pegawai sehingga dapat diaplikasikan dalam beragam setting organisasi, termasuk pendidikan atau sekolah. 
BEduManageRs Journal

Borneo Educational Management and Research Journal, Vol.2, No.1, 2021

ISSN: 2747-0504

Menurut Nanang Fattah (1999), Prestasi Kerja dapat merupakan gambaran yang nyata dari keterampilan dan kemampuan seseorang yang diungkapkan melalui pengetahuan, sikap, dan ketrampilan serta motivasi dalam menghasilkan sesuatu. Sedangkan menurut Bernardin dan Russel dalam Ahmad S Ruky (2001), penampilan dapat didefinisikan sebagai catatan tentang hasil yang dicapai secara spesifik dari pekerjaan yang spesifik sesuai tugasnya atau tanggungjawabnya dalam waktu atau periode tertentu.

Selanjutnya Anwar Prabu Mangkunegara (2001), mengemukakan bahwa kinerja pada dasarnya merupakan performa atau tampilan yang nyata baik secara kualitas maupun kuantitas yang dilakukan oleh seorang pegawai dalam melaksanakan tugasnya sesuai dengan lingkup tanggung jawab yang diembannya.

Sementara menurut Murray Ainsworth et.el (2002), pada dasarnya penampilan atau kinerja merupakan hasil atau nilai yang diperoleh, kinerja berarti hasil atau hasilnya. Yang merupakan puncak keberhasilan dari orang, termasuk sumber daya dan lingkungan tertentu yang dibawa bersama-sama , dengan tujuan untuk menghasilkan hal-hal tertentu, apakah produk yang kongkrit ataupun berupa layanan jasa yang tidak nyata. Sejauh ini hasil interaksi dalam sebuah hasil dari tingkat yang diinginkan dan kualitas, pada tingkat biaya yang disepakati, kinerja akan dinilai sebagai satisfaktory, baik, atau sangat baik.

Kinerja dalam suatu organisasi dapat dikatakan meningkat jika memenuhi indikator-indikator diantaranya; Kualitas dari hasil pekerjaannya, Ketepatan waktu mengerjakan, Inisiatif, Kecakapan dalam pekerjaan, Komunikasi yang efektif. Pengukuran kinerja dimulai dari penentuan ukuran kerja, teori atribusi bahwa orang cenderung merasa tidak puas dengan hanya mengetahui apa yang dikerjakaan orang lain, tetapi sering kali mencari alasan mereka melakukan pekerjaan tersebut. Kegiatan belajar mengajar merupakan kinerja yang berasal dari faktor internal dan faktor eksternal dapat memberikan pengaruh yang kuat terhadap kinerja guru yang datang dari rekan kerja maupun dari kepala sekolah. Dimensi kinerja dari suatu pekerjaan yang lain biasa berbeda tergantung uraian pekerjaannya (job description), kualitas kerja (quality of work), ketepatan kerja (prompteness), inisiatif (initiative), kemampuan (capability), dan komunikasi ( communication ). Kinerja guru dapat dikatakan baik apabila memiliki kesetiaan, prestasi kerja, kejujuran, kedisiplinan, kreativitas, kerja sama, kepemimpinan, kepribadian prakarsa, kecakapan, dan tanggung jawab.

Berdasarkan hasil análisis dan kajian teori tentang kinerja guru dapat disimpulkan bahwa yang dimaksud dengan kinerja guru adalah kegiatan guru yang disampaikan selama proses pembelajaran berlangsung. Adapun indikatornya adalah: (1) pembuatan program pengajaran, (2) pelaksanaan kegiatan program pengajaran, (3) pelaksanaan evaluasi belajar siswa, (4) analisis hasil evaluasi, dan (5) penyusunan dan pelaksanakan program perbaikan (remedial) dan pengayaan (bimbingan).

\section{Motivasi Kerja Guru}

Istilah motivasi (motivation) menurut Winardi (2001:1) berasal dari bahasa latin, yaitu moveré yang artinya mengerakan (to move). Berdasarkan definisi di atas bahwa motivasi merupakan dorongan dari dalam diri peribadi untuk meningkatkan aktualisasi diri. Untuk mencapi tujuan yang diinginkan atau untuk memenuhi kebutuhan hidup. Selanjutnya menurut Mitchel dalam Winardi (2001:24) konteks motivasi mewakili proses psikologikal yang menyebabkan timbulnya pengarahan, dan motivasi persistensi kegiatan sukarela yang ditujukan ke arah pencapaian tujuan tertentu.

Motivasi merupakan peroses perubahan tingkah laku yang telah diperkuat pada waktu yang lalu dalam menghadapi kegagalan dan berusaha untuk memperbaikinya. Gay et al dalam Winardi (2001:2) mengungkapkan bahwa motivasi merupakan hasil sejumlah proses yang bersifat internal atau eksternal bagi seorang individu, yang menyebabkan timbulnya sikap antusiasme dan presistensi dalam hal melaksanakan kegiatan tertentu. Merupakan dorongan dari individu untuk meningkatkan kemampuan kemampuan yang ada dalam diri seseorang untuk mecapai harapan yang diinginkan.

Dapat disimpulkan bahwa motivasi kerja adalah adalah suatu dorongan jiwa yang membuat seseorang tergerak untuk melakukan tindakan yang produktif, baik yang berorientasi 
BEduManageRs Journal

Borneo Educational Management and Research Journal, Vol.2, No.1, 2021

ISSN: 2747-0504

kerja untuk menghasilkan uang maupun yang tidak. Adapun indikator tersebut sebagai berikut: 1) keinginan untuk kerja, 2) tumbuhnya kerja, 3) terciptanya situasi dan kondisi kerja yang kondusif, 4) tersedianya imbalan, 5) pengakuan, 6) kebutuhan akan kekuasaan, 7) kebutuhan akan berafilitasi, dan 8) inovatif dan kreatif.

\section{Hasil Penelitian yang Relevan}

Beberapa penelitian yang menyerupai dengan penelitian ini kiranya penulis kemukakan, diantaranya sebagai berikut: Hasil penelitian Tesis Nugraha susanto (2000). membahas tentang Pelaksanaan penilaian fungsional Guru dan pengaruhnya terhadap kualitas kinerja guru Sekolah Dasar, menyimpulkan hal sebagai berikut: Terjadi korelasi yang besar tingkat abilitas kerja dengan hubungan fungsional sangat nyata. Penelitian ini menujukan adanya hubungan positif antara penilaian fungsional guru terhadap kinerja guru Sekolah Dasar.

Dahman Darajat (2001), mengkaji tentang Implikasi kebijakan fungsionalisasi jabatan dari pengawas sekolah terhadap peningkatan kinerja guru si sekolah. Tingkat kinerja guru tergolong tinggi meskipun harus menjalankan mengajar didua kelas namun kemampuan guru dalam memecahkan pengajaran melaksanakan kegiatan belaja mengajar dan penghasilan produktivitas tergolong tinggi.

Penelitian mengungkapkan bahwa kinerja guru diukur bukan hanya dari dalam diri tetapi dari luar lingkungan dimana guru tersebut bekerja, baik kegiatan kelompok kerja guru, latar belakang pendidikan, penilaian kepemimpinan kepala sekolah, dan motivasi itu semua merupakan faktor dari luar atau lingkingan dimana guru tersebut dapat melaksanakan tugasnya dengan baik sehingga memperoleh hasil yang sesuai harapan.

Dengan demikian motivasi kerja guru dapat menjadi dasar begaimana guru berperilaku dan bekerja sesuai dengan motivasinya, hal ini akan berpengaruh pada kualitas kinerjanya, guru yang memiliki motivasi kerja yang tinggi sudah pasti akan berupaya semaksimal mungkin untuk melaksanakan tugasnya dengan baik sesuai dengan harapannya, dia akan berupaya untuk melakukan hal yang terbaik sehingga menghasilkan kinerja yang baik. Apa lagi apabila di dukung oleh situasi dan kondisi lingkungan yang memberi kesempatan guru melakukan aktifitasnya dengan baik, maka kinerja guru dapat meningkat sehingga hasil yang ditargetkan dapat tercapai.

\section{Hubungan Motivasi Kerja dengan Kinerja Guru}

Motivasi kerja guru yang merupakan dorongan yang timbul dalam melaksanakan tugas atau pekerjaannya. Dorongan tersebut dapat terjadi oleh faktor itrinsik dan ekstrinsik sehingga ada keinginan untuk pemenuhan kebutuhan dari segi konpensasi, iklim kerja, kepuasan kerja, dedikasi, kemampuan dan keterampilan.

Kinerja guru yang dimaksud dalam penelitian ini merupakan hasil unjuk kerja yang ditampilkan guru menyangkut seluruh aktivitas dan tanggung jawabnya dalam menjalankan tugas sebagai pengajar, pembimbing dan pendidik bagi para sisiwa. Diduga terdapat hubungan positif antara motivasi kerja terhadap kinerja guru di sekolah-sekolah Yayasan Pembinaan Islam Yabis Bontang

Dorongan yang muncul pada guru berupa motivasi dapat meningkatkan hasil optimal yang ditujukan guru menyangkut seluruh aktivitas dan tanggung jawabnya dalam mengemban amanah atau tugas sebagai pengajar, pembimbing dan pendidik bagi para siswa. Kinerja guru dalam menampilkan atau unjuk kerja sangat dipengaruhi oleh kuat tidaknya motivasi kerja yang ada dalam diri guru.

Dengan demikian diduga terdapat kontribusi motivasi kerja terhadap kinerja guru di sekolah sekolah Yayasan Pembinaan Islam Yabis. Selanjutnya untuk memperkuat kajian ini penulis ajukan hipotesis penelitian sebagai berikut; 1) Terdapat hubungan yang positif antara motivasi kerja dengan kinerja guru di sekolahsekolah Yayasan Pendidkan Islam Yabis Bontang. 2) Motivasi kerja memberikan kontribusi yang positif terhadap kinerja guru di Yayasan Pendidikan Islam Yabis.

\section{METODE PENELITIAN}

Penelitian ini dilaksanakan pada unit-unit sekolah yang ada Yayasan pendidikan Yabis Bontang sebagai objek penelitian. Sedangkan sebagai subjek penelitiannya adalah para guruguru dari unit TK, SD, SMP dan SMA, sebanyak 92 guru. 
BEduManageRs Journal

Borneo Educational Management and Research Journal, Vol.2, No.1, 2021

ISSN: 2747-0504

Dalam penelitian ini penulis menggunakan metode expost facto yang pengolahan datanya dilakukan dengan teknik korelasional. Kerlinger yang dikutif oleh Sugiyono (2004) mengemukakan bahwa penelitian ex post facto merupakan penelitian yang berupaya menemukan secara empiris yang dilakukan secara sistematis.

Dalam hal ini peneliti tidak melakukan kontrol terhadap variable-variabel bebas karena manifestasinya sudah terjadi atau bisa juga disebabkan karena variabel-variabel tersebut secara inheren tidak dapat dimanipulasi. Untuk memperoleh data di lapangan maka penelitian ini menggunakan instrument berupa kuesioner yang disusun berdasarkan indikator-indikator. Data yang dibutuhkan dalam penelitian ini adalah data tentang motivasi kerja guru (X), dan kinerja guru (Y).

Design penelitian direncanakan menggunakan teknik korelasional. Konstelasi hubungan antara variabel yang satu dengan variabel yang lain dalam penelitian ini adalah motivasi kerja, dan kinerja guru

\section{Operasionalisasi Variabel Penelitian}

Penelitian meliputi dua variabel penelitian yaitu satu variabel bebas dan satu variabel terikat. Oleh karena itu dalam penelitian ini memerlukan dua macam instrumen yang digunakan untuk mengumpulkan data yaitu: instrumen Kinerja Guru dan Motivasi Kerja guru .

Variabel Kinerja Guru (Y). Kinerja guru adalah kegiatan guru yang disampaikan selama proses pembelajaran berlangsung. Definisi Operasional kinerja guru adalah skor kegiatan guru yang diperoleh dari hasil pengukuran tentang kinerja guru dengan menggunakan instrumen kinerja berdasarkan indikator. 1) penyusunan program pengajaran, 2) pelaksanaan kegiatan kegiatan program pengajaran, 3) pelaksanaan evalusi belajar siswa, 4) analisis hasil evaluasi, 5) penyusunan dan melaksanakan program perbaikan (remedial) dan pengayaan (bimbingan) dengan responden kepala sekolah unit analisis guru.

Variabel Motivasi Kerja (X). Definisi Konseptual. Motivasi kerja adalah adalah suatu dorongan jiwa yang membuat seseorang tergerak untuk melakukan tindakan yang produktif, baik yang berorientasi kerja untuk menghasilkan uang maupun yang tidak menghasilkan.

Definisi Operasional motivasi kerja guru adalah skor yang diperoleh dari hasil pengukuran tentang motivasi kerja seorang guru menggunakan instrumen dengan idikator. 1) Keinginan untuk kerja, 2) tumbuhnya kerja, 3) terciptanya situasi dan kondisi kerja yang kondusif, 4) tersedianya imbalan, 5) pengakuan, 6) kebutuhan akan kekuasaan, 7) kebutuhan akan berafilitasi, dan 8) inovatif dan kreatif, dengan unit analisis guru dan responden guru.

\section{Sumber Data dan Alat Pengumpulan Data}

Dalam penelitian ini yang menjadi sumber data adalah guru yang ada di Lembaga pendidikan Yabis Bontang dari unit TK, SD, SMP dan SMA yaitu sebanyak 92 guru.

Dari seluruh guru yang ada di unit-unit pada Lembaga Pendidikan Yabis Bontang yang akan dijadikan sampel penelitian dengan menggunakan teknik Proportional Random Sampling, yaitu menetukan sampel dengan cara sampel diambil dari perwakilan tiap-tiap kelompok unit sekolah yang ada dalam populasi yang jumlahnya disesuaikan dengan jumlah anggota subjek. Jumlah sampel penelitian yang akan dijasikan subjek penelitian sebanyak 92 yang akan dilakukan secara random proporsional.

\section{Instrumen Kinerja Guru (Y)}

Kalibrasi Instrumen Variabel Kinerja Guru

a. Kesahihan instrumen kinerja guru. Kesahihan (validity) instrumen kinerja guru berdasarkan pada uji butir instrumen dengan mempergunakan teknik uji validitas Point Biserial. Hasil uji coba instrumen kinerja guru, diperoleh item valid sebanyak 68 item. Sehinggga Instrumen kinerja guru yang digunakan dalam penelitin ini sebanyak 68 item.

b. Keterandalan instrumen kinerja guru. Keterandalan (reliability) instrumen dalam penelitian ini menggunakan uji reliabilitas Alpha Cronbach,

\section{Instrumen Motivasi Kerja Guru (X)}

Kalibrasi Instrumen Motivasi Kerja Guru

a. Kesahihan instrumen Motivasi Kerja Guru. Kesahihan (validity) instrumen Motivasi Kerja Guru berdasarkan pada uji butir instrumen dengan mempergunakan teknik uji validitas Point Biserial. Hasil uji coba 
BEduManageRs Journal

Borneo Educational Management and Research Journal, Vol.2, No.1, 2021

ISSN: 2747-0504

instrumen motivasi kerja guru, diperoleh beberapa item yang valid sebanya 64 item.

\begin{tabular}{|l|l|l|l|l|}
\hline 1 & .850 & .722 & .714 & 6.24831 \\
\hline
\end{tabular}

b. Keterandalan instrumen motivasi kerja guru. Berdasarkan perhitungan dengan menggunakan microsoft excel. Nilai Alpha Cronbach adalah 1,037. Dapat disimpulkan bahwa questioner untuk variabel motivasi kerja Guru memiliki tingkat reliabilitas yang dapat diandalkan.

\section{Teknik Pengolahan dan Analisis Data}

Langkah yang ditempuh dalam pengolahan dan analisis data sebagai berikut:

a. Pengujian normalitas distribusi dilakukan dengan rumus "Shapiro-Wilk" kurva normal melalui program Spss seri 17.

b. Uji homogenitas dilakukan untuk mengetahui homogenitas kelompok data populasi. Uji ini dilakukan dengan mengelompokkan data berdasarkan variabel Motivasi Kerja Guru (X), dan Kinerja Guru (Y). untuk uji homogenitas varians digunakan "Levene Test".

c. Persamaan Regresi Sederhana. Persamaan regresi yang dicari dalam penelitian ini meliputi variabel Motivasi Kerja Guru (X) dan variabel Kinerja Guru (Y).

\section{HASIL DAN PEMBAHASAN}

Uji normalitas variabel kinerja guru $(\mathrm{Y})$ atas variabel motivasi kerja Data $\mathrm{X}$ nilai sig. 0,689> 0,05 mempunyai populasi yang berdistribusi normal, sehingga memenuhi persyatan pengujian selanjutnya.

Uji Homogenitas varians kelompok data variabel Kinerja Guru (Y) atas variabel Motivasi Kerja (X) di uji dengan menggunakan Levene Test, berdasarkan hasil perhitungan diperoleh nilai Uji Levene di atas memperlihatkan hasil Sig $=0,334 \geq 0,05$. Ini mengandung arti bahwa kedua kelompok $\mathrm{X}$ dan $\mathrm{Y}$ adalah homogen.

\section{Hubungan Motivasi Kerja (X) dengan Kinerja Guru (Y).}

Berdasarkan hipotesis pertama yang berbunyi terdapat hubungan positif antara motivasi kerja (X) dengan Kinerja Guru (Y).

\section{Korelasi X ke Y}

Model Summary

\begin{tabular}{|c|c|c|c|c|}
\hline Model & $\mathrm{R}$ & $\begin{array}{c}\mathrm{R} \\
\text { Square }\end{array}$ & $\begin{array}{c}\text { Adjusted } \mathrm{R} \\
\text { Square }\end{array}$ & $\begin{array}{c}\text { Std. Error of } \\
\text { the Estimate }\end{array}$ \\
\hline
\end{tabular}

Predictors: (Constant), $\mathrm{X}$

Dependent Variable: Y

Berdasarkan hasil perhitungan diperoleh koefisien korelasi (r) sebesar 0,850. Hubungan fungsional antara variabel kinerja guru (Y) dengan motivasi kerja (X) sebesar r 0,850 artinya bahwa variabel kinerja guru memiliki hubungan yang positif dengan motivasi kerja guru.

Pengujian hipotesis yang menyatakan terdapat hubungan Motivasi kerja (X) terhadap Kinerja Guru (Y) diperlukan uji signifikansi koefisien korelasi, yaitu dengan menggunakan uji t. diperoleh $\mathrm{t}_{\text {hitung }}$ sebesar 5,469 $>\mathrm{t}_{\text {tabel }}$ sebesar $2,43(\mathrm{dk}=38$ pada $\alpha=0,01)$. Hal ini berarti bahwa hubungan antara motivasi kerja dengan variabel Kinerja Guru (Y) adalah signifikan.

Berdasarkan hasil pengujian terhadap hipotesis pertama, dapat disimpulkan bahwa $\mathrm{H}_{\mathrm{o}}$ ditolak, artinya $\mathrm{H}_{1}$ yang menyatakan terdapat hubungan positif antara motivasi kerja (X) dengan Kinerja Guru (Y) adalah signifikan dapat diterima.

\section{Kontribusi Motivasi Kerja (X) terhadap Kinerja Guru (Y).}

Berdasarkan hipotesis kedua yang berbunyi Motivasi kerja (X) memberikan kontribusi yang positif terhadap Kinerja Guru (Y). Hasil perhitungan diperoleh koefisien korelasi (r) sebesar 0,850. Hubungan fungsional antara variabel kinerja guru (Y) dengan motivasi kerja (X) sebesar R Square 0,722. Artinya bahwa $72,2 \%$ variabel $\mathrm{Y}$ dipengaruhi variabel $\mathrm{X}$ dan sisanya sebesar $27,8 \%$ dipengaruhi oleh hal-hal lain yang tidak dapat diprediksi. Hal ini memberikan makna bahwa setiap peningkatan motivasi kerja guru akan menyebabkan kenaikan Kinerja Guru sebesar $72 \%$. Berdasarkan hasil perhitungan uji signifikansi regresi pada tabel 20, diperoleh $F_{\text {hitung }}=98,60>F_{\text {tabel }(0,01)}=3,57$. Hasil pengujian signifikansi regresi tersebut menujukkan pengaruh Motivasi Kerja Guru (X) terhadap Kinerja Guru (Y) adalah sangat signifikan. 
BEduManageRs Journal

Borneo Educational Management and Research Journal, Vol.2, No.1, 2021

ISSN: 2747-0504

Pengujian hipotesis yang menyatakan terdapat pengaruh Motivasi Kerja Guru $\left(\mathrm{X}_{2}\right)$ terhadap Kinerja Guru (Y) diperlukan uji signifikansi koefisien korelasi, yaitu dengan menggunakan uji t diperoleh $\mathrm{t}$ hitung sebesar $9,93>\mathrm{t}_{\text {tabel }}$ sebesar 2,43 ( $\mathrm{dk}=38$ pada $\alpha=0,01)$. Hal ini dapat disimpulkan bahwa $\mathrm{H}_{\mathrm{o}}$ ditolak, artinya $\mathrm{H}_{1}$ yang menyatakan terdapat pengaruh Motivasi Kerja Guru (X) terhadap Kinerja Guru (Y) adalah signifikan dapat diterima.

\section{Pembahasan Hasil Penelitian}

Pengujian hipotesis dalam penelitian ini, menggunakan regresi dan korelasi sederhana dengan menggunakan program microsoft exel dan juga SPSS 17.

Berdasarkan hasil uji analisis terhadap kedua variabel tersebut maka dapat disimpulkan bahwa terdapat hubungan yang positif antara motivasi kerja dengan Kinerja Guru, setiap penambahan satu unit dari variabel motivasi kerja akan menyebabkan kenaikan kinerja guru sebesar 0,722. Memperhatikan nilai persentase dari kontribusi motivasi kerja terhadap Kinerja Guru merupakan hasil dari kuatnya motivasi kerja untuk meningkatkan kinerja guru

Motivasi kerja dapat mempengaruhi Kinerja Guru terutama dalam hal; 1) keinginan untuk kerja, 2) tumbuhnya kerja, 3) terciptanya situasi dan kondisi kerja yang kondusif, 4) tersedianya imbalan, 5) pengakuan, 6) kebutuhan akan kekuasaan, 7) kebutuhan akan berafilitasi, dan 8) inovatif dan kreatif.

Hasil temuan ini mengisyaratkan bahwa Kinerja Guru yang sangat dibutuhkan dalam upaya meningkatkan kuaitas pendidikan di unit-unit sekolah yang ada pada Lembaga pendidikan Yabis Bontang, banyak dipengaruhi oleh seberapa kuatnya motivasi kerja guru. Semakin kuat motivasi kerja guru dalam melaksanakan tugas sekolah, maka akan berdampak positif terhadap peningkatan kinerja guru dalam melaksanakan tugasnya di sekolah.

\section{F. KESIMPULAN DAN SARAN}

\section{Keimpulan}

Berdasarkan data yang diperoleh, hasil pengujian hipotesis, dan pembahasan hasil penelitian dapat disimpulkan sebagai berikut:

a. Terdapat hubungan yang positif antara motivasi kerja dengan kinerja Guru pada unit-unit sekolah pada Lembaga pendidikan Yabis Bontang. b. Motivasi kerja memberikan kontribusi yang positif terhadap kinerja guru di unit-unit sekolah pada Lembaga pendidikan Yabis Bontang.

\section{Saran}

Beberapa saran untuk peningkatan kinerja guru sebagai berikut.

a. Saran kepada para guru di Lembaga pendidikan Yabis Bontang. Hasil penelitian yang telah dilakukan menunjukkan bahwa kinerja guru secara keseluruhan tergolong cukup baik. Hal ini dapat dilihat dari rata rata kinerja guru berada diatas rata skor ideal. Namun demikian, disarankan kepada para guru perlu meningkatkan motivasi dan upaya untuk terus menerus meningkatkan kemampuan dan aktivitas sehingga kinerja guru dapat meningkat lebih baik khususnya di masa pandemic Covid 19.

b. Saran kepada para pakar serta penentu kebijakan di Lembaga Pendidikan Yabis Bontang. Motivasi kerja dapat memberikan kontribusi positif terhadap kinerja guru . Oleh karena itu disarankan agar guru perlu berupaya meningkatkan motivasi kerjanya dengan menjalin hubungan yang lebih harmonis dan saling mendukung terhadap perkembangan dan kemajuan sekolah, sehingga kinerja guru di masa pandemic Covid 19 diharapkan dapat tercapai dengan baik.

\section{DAFTAR PUSTAKA}

Ahmad S Ruky. 2001. Sistem Manajemen Kinerja, Struktur Organisasi dan Tata Kerja Rumah Sakit Kanker, Jakarta, Gramedia.

Anwar Prabu Mangkunegara. 2001. Manajeman Sumber Daya Manusia Perusahaan, Rosda Karya, Bandung.

Ary Ginanjar Agustian. 2008. Kepemimpinan Berdasarkan Kecerdasan Emosi dan Spiritual, (ESQ), www.goodreads.com, Religion, Islam.

Dadi Permadi. 2001. Manajemen Berbasis Sekolah dan Kepemimpinan Mandiri 
BEduManageRs Journal

Borneo Educational Management and Research Journal, Vol.2, No.1, 2021

ISSN: 2747-0504

Kepala pembinaan yang intensif terhadap guru. Kepala Sekolah Bandung: PT Sarana Panca Karya Nusa.

Darwis S. Gani, Djoehana S, dan Sumardi,. 2008. Kepemimpinan dan Organisasi Pendidikan, Bogor Universitas Pakuan:

Dahman Darjat. 2001. Implikasi Kebijakan Fungsional Jabatan Pengawas Kepala Sekolah Perhadap peningkatan Kinerjanya. UPI Bandung.

Davis, Keith. 1985. Organizational Behavior, Human Behavior at Work, Third Edition, McGraw- Hill International Edition..

Farid Hadjiri, H. 2000. Gaya kepemimpinan Birokrat Di Era Reformasi, Jakarta, Penerbit Student Press.

Franklyn S. Haiman. 1995. Group Leadersship and Democratic Action, Huoght Illions Mifflin Company.

Hadari Nawaw. 1992. Manajemen Sumber Daya Manusia. Gadjah Mada Press, Jogyakarta.

Harsey, Paul and Kenneth H. Blanchhard. 1997. Management of Organizational Behavior, New Jersey: prentice-Hal Inc.

Hasibuan, Malayu P. 2003. Dasar-dasar Manajemen. Bandung: Rosdakarya.

James Mac Gregor Burns. 1979. Leadership - James MacGregor Burns - Google Books Business $\&$ Economics.

JS, Husdarta. 2004. Psikologi Olahraga, Fakultas Pendidikan Olahraga dan Kesehatan, Universitas Pendidikan Indonesia.

Kartini Kartono. 2005. Pemimpin dan kepemimpinan. Jakarta: PT Raja Grafindo Persada.

Mahmudi. 2005. Manajemen Kinerja Sektor Publik. Yogyakarta: Akademi Manajemen Perusahaan YKPN.

Murray Ainsworth et.el. 2002. Managing Performance. Millership. Japan.
Nanang Fattah. 2003. Landasan Manajemen Pendidikan. Penerbit PT. RosdaKarya, Bandung.

Nugraha Susanto. 2000. Pelaksanaan Penilaian Jabatan Fungsional Guru dan Pengaruhnya Terhadap Kualitas Kinerja Guru. UPI Bandung.

Robbins, Stephen P. 1993. Organizational Behavior. Prentice Hall International, Canada.

Robert G. Owens. 1998. Organization Behavior In Education Fourth Edition. Boston: Allyn and Bacon.

Siagian, Sondang P. 2003. Teori dan Praktek Kepemimpinan (cetakan kelima). Jakarta: Rineka Cipta.

Sugiyanto. 2003. Model-Model Pembelajaran Inovatif. Penerbit PT Rosda Karya.

Sugiyono. 2013. Metode Penelitian Pendidikan. Alfabeta Press, Bandung.

Sutisna Oteng. 1989. Admistrasi Pendidikan, Dasar Teori Untuk Praktek Profesional. Bandung: Penerbit Angkasa.

Tjiptono F. 2001. Kualitas Jasa: Pengukuran, Keterbatasan dan Implikasi. Manajerial. Majalah Manajemen Usahawan Indonesia. Jakarta.

Universitas Galuh. 2014. Pedoman Penulisan Usul Penelitian dan Tesis \& Artikel Jurnal Ilmiah. Program Pascasarjana Universitas Galuh.

Winardi, J. 2001. Motivasi dan Pemotivasian dalam Manajemen. Raja Grafindo Persada. 